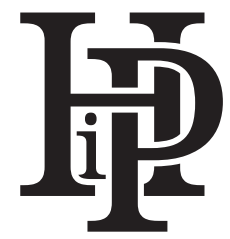

Historia i Polityka

Nr 27(34)/2019, ss. 163-165

www.hip.umk.pl (c) (i) $\Theta$

ISSN 1899-5160, e-ISSN 2391-7652

DOI: http://dx.doi.org/10.12775/HiP.2019.010

Kamil PIETRASIK (D)

Uniwersytet Łódzki, Wydział Studiów Międzynarodowych i Politologicznych, Polska

\title{
Daniel Koehler, Understanding Deradicalization Methods, Tools and Programs for Countering Violent Extremism, London-New York 2017, ss. 306
}

$\mathbf{Z}$ jawisko radykalizacji wśród osób, które decydują się na odmianę swojego dotychczasowego życia, jest w ostatnich dekadach dość częste. Powoduje ono pojawienie się licznych problemów w kontekście bezpieczeństwa państw. Radykałowie dopuszczają się aktów przemocy: wysadzania się w powietrze, podkładania bomb pod pojazdy mechaniczne, obiekty wojskowe, urzędy itp. W wyniku działań służb nie zawsze dochodzi do likwidacji zamachowca, ale do zatrzymania i skazania na kilkuletnie pozbawienie wolności, dożywocie lub karę śmierci. Z osobami zatrzymanymi pracuje się nad zmianą ich spojrzenia na świat przez odrzucenie radykalnych postaw. Skutkiem tego jest zjawisko zwane deradykalizacją. Aby lepiej zrozumieć ten proces, Daniel Koehler przedstawia praktyki oraz dokonuje próby analizy programów, których celem jest resocjalizacja osób podejrzanych o radykalne poglądy w wybranych państwach. Omawiana praca składa się z dziewięciu rozdziałów. We wstępie autor wskazał na istotny fakt związany z procesem deradykalizacji, a mianowicie na wy- darzenie ze stycznia 2014 r., kiedy to Komisja Europejska opublikowała zmienioną strategię zwalczania aktów terroryzmu, sugerując wzmocnienie polityki interwencyjnej. Każde państwo członkowskie Unii Europejskie zostało wówczas poproszone o stworzenie krajowych programów zwalczania terroryzmu i bezpieczeństwa (s. 2). Wydarzenie to było swoistym preludium do tego, by poszczególne kraje wdrożyły programy dotyczące deradykalizacji, a także pochyliły się nad odpowiednimi instrumentami prawnymi. Pierwszy rozdział, Methods, Sources, State of the Art, prezentuje metody badawcze, które zastosował autor: przegląd literatury oraz prezentację obecnego stanu wiedzy. Autor dochodzi do wniosku, że grupy ekstremistów lub terrorystów charakteryzują się mniej lub bardziej wyrafinowanymi mechanizmami decyzyjnymi, a ich działanie oparte jest na hierarchii. Niemniej nawet grupy bardziej brutalne (np. Skinhead) wykazują zaskakujące umiejętności logistyczne i organizacyjne (s. 23). Kolejny rozdział, The Theory of Radicalization and Deradicalization, rozpoczyna się od stwierdzenia, 
iż zrozumienie zjawiska deradykalizacji wymaga stworzenia koncepcji teoretycznej uwzględniającej różne mechanizmy psychologiczne skłaniające człowieka do przemocy (tj. eskalację lub radykalizację). "Radykalizacja” dopiero niedawno weszła w główny nurt debaty politycznej oraz naukowej. Przed atakami z 11 września 2001 r. powszechniej zwykło się mówić o „podstawowych przyczynach” terroryzmu (s. 66). Autor dochodzi do wniosku, iż „radykalizacja” jest używana do opisu w jaki sposób konkretna osoba „staje się terrorystą” lub „ekstremistą”. Jak twierdzi dzieje się to zazwyczaj w wyniku procesu przejmowania idei promujących stosowanie przemocy. Z perspektywy Komisji Europejskiej „radykalizacja” jest procesem obejmującym „opinie, poglądy i idee, które mogą prowadzić do aktów terroryzmu". Autor przytacza zaproponowane przez innych badaczy (Marc Sageman, Michael Taarnby, Paul Gill, Quentin Wiktorowicz, Fathali Moghaddam, Clark McCauley), „modele radykalizacji” ukazujące etapy radykalizacji postaw. Kolejny rozdział, Deradicalization Programs and Counter-Terrorism, poświęcony jest opisom programów wdrażanych na Bliskim Wschodzie, w Azji Południowo-Wschodniej oraz Europie Zachodniej. Autor pokazuje sposób zaangażowania w ich tworzenie poszczególnych instytucji państwowych zajmujących się kwestiami bezpieczeństwa. Ukazuje on również wady i zalety włączania w opisywane działania służ specjalnych. W rozdziale Typology and Actors of Deradicalization and Disengagement Programs (DDPs) Koehler zaprezentował autorską typologię stosowanych mechanizmów i programów. Ma on charakter innowacyjny i może zainspirować do dyskusji oraz podjęcia kolejnych badań. Na uwagę zasługuje zamieszczona w konkluzji tabela, która w prosty sposób obrazuje poszczególne typy programów deradykalizacyjnych. Family Counseling as a Special Case of Deradicalization to rozdział, w którym skupiono się na roli rodziny i wyznawanych wartości w kontekście podjęcia prób deradykalizacji osób podejrzanych o skrajne poglądy lub skłonności do popełnienia aktów terroryzmu. Autor podjął próbę analizy programów działających w takich państwach jak: Dania, Niemcy, Holandia, Francja. Rozdział Effects and Effectiveness of Deradicalization Programs. The Questions of Evaluation, Working Standards, and Program Design to Ensure Impact poświęcony został ukazaniu skuteczności programów deradykalizacji. Autor poświęca wiele uwagi Niemcom, ukazując aktywność tamtejszych ekstremistów w mediach społecznościowych. Skupił się głównie na radykałach prawicowych. Wspomniany wątek nie jest marginalny, albowiem jak dowiadujemy się z prezentowanych wykresów zawierających liczby politycznie umotywowanych przestępstw z użyciem przemocy w latach 2001-2014 oraz demonstracji zorganizowanych przez środowiska radykalnie prawicowe, problem ten na obszarze niemieckim nie może zostać niezauważony. Następny rozdział, Moral and Methodological Problems of Deradicalization and Disengagement Programs, to analiza wad realizowanych programów deradykalizacji, które wdraża się np. w Malezji, Arabii Saudyjskiej i innych bliskowschodnich oraz azjatyckich krajach. W tym kontekście autor dochodzi do wniosku, że programy deradykalizacji, w szczególności państwowe, są w istocie próbami podważenia w tych państwach swobód obywatelskich (s. 201). Zauważa, iż programy w krajach europejskich są realizowane $\mathrm{z}$ poszanowaniem praw człowieka. Kolejny rozdział, Tools and Methods. Practical Aspects of Deradi- 
calization Work, skupiony został wokół praktycznych kwestii deradykalizacji. Autor zaprezentował metody przywracania do normalnego funkcjonowania w społeczeństwie osób podejrzanych o radykalne poglądy. Jak zauważa w tym celu stosowane są rozmaite techniki resocjalizacyjne: malarstwo, sztuka, muzyka, kształcenie i edukacja zawodowa. Ostatni rozdział: The Global Deradicalization and CVE Landscape at a Glance, to przegląd i omówienie programów deradykalizacji w krajach europejskich: Wielka Brytania, Dania, Irlandia Północna, Niemcy, Holandia, Francja, Szwecja, Austria oraz na Bliskim Wschodzie, np.: Arabia Saudyjska, Jemen,
Irak, Izrael, Jordania. Na uwagę zasługuje również to, iż autor zobrazował metody i skutki „nawracania” radykałów w krajach afrykańskich (Sudan, Uganda, Kenia, Nigeria, Tunezja, Egipt, czy Somalia i Mauretania) oraz w Australii i Oceanii.

Publikację wzbogacają liczne tabele, ryciny i wykresy, które czytelnie obrazują omawiane kwestie. Reasumując, książka Daniela Koehlera jest innowacyjna i może być wskazówką dla przyszłych badaczy, którzy podejmą się w przyszłości dociekania przyczyn oraz oceny skuteczności wdrażanych przez poszczególne państwa programów deradykalizacji. 